Slobodan Cvetanović ${ }^{1}$

University of Niš, Faculty of Economics

\section{Vladimir Nedić ${ }^{2}$}

Technical College of applied studies in Kragujevac

\section{Lena Despotović ${ }^{3}$}

University of Belgrade, Faculty of Organizational Sciences
ORIGINAL SCIENTIFIC ARTICLE

doi:10.5937/ekonomika1903013C

Received: Jul 12. 2019.

Accepted: September, 09. 2019.

\title{
THE ANALYSIS OF BUSINESS CONDITIONS IN WESTERN BALKAN COUNTRIES
}

\begin{abstract}
The paper analyses business conditions in Western Balkan countries (Albania, Bosnia and Herzegovina, Macedonia, Serbia and Montenegro) and Croatia as an EU member in the period 2006-2018, based on three indicators of Doing Business: a) Country ranking b) Ranking change and c) Distance to frontier measure. The obtained results showed that during the observed period Western Balkan countries significantly, but still insufficiently improved creation of favourable conditions for business activities. By comparing the three indicators above for the Western Balkan countries and Croatia it was found that the EU membership did not automatically mean the presence of more favourable conditions in comparison to those present in the non-member countries of this regional economic integration.
\end{abstract}

Key words: ease of doing business, Western Balkan countries, Croatia, ranking, ranking change

JEL classification: . M21, K20, K40

\section{АНАЛИЗА УСЛОВА ПОСЛОВАҢА У ЗЕМЪАМА ЗАПАДНОГ БАЛКАНА}

\begin{abstract}
Апстракт
У раду су сагледавани услови пословања земала Западног Балкана (Албанија, БиХ, Македонија, Србија, Црна Гора) и Хрватске као чланище Европске уније у периоду 2006-2018. на основу три показатеља Лакоће пословања (Доинг Бусинесс): а) ранга земаља, б) промене ранга и и) прочене удаљености појединих привреда од најбољих показатеља, тј. мере растојана од границе (Дистание то фронтиер меасуре). Добијени резултати су показали да су земье Западног Балкана у посматраном периоду у целини, значајно али још увек недовољно, напредовале у погледу стварања повољних услова за пословање предузећа. Упоређивањем претходно поменута три показатеља за земље Западног Балкана и Хрватске, дошло се до
\end{abstract}

\footnotetext{
${ }^{1}$ slobodan.cvetanovic@eknfak.ni.ac.rs

${ }^{2}$ vnedic@kg.ac.rs

${ }^{3}$ lenaa.despotovic@gmail.com
} 
закључка да чланство у ЕУ не значи аутоматски постојање повољнијих услова пословаьа од оних који постоје у земьама које нису чланице ове регионалне економске интеграције.

Кључне речи: лакоћа пословања, земље Западног Балкана, Хрватска, ранг, промена ранга

\section{Introduction}

The most significant mission of a country related to business is realised in the creation of best conditions for business activities (Cavusgil, Ghauri \& Akcal, 2012; Prokopović, Jelić \& Veličković, 2017). One of numerous aims that should be realised within the support to business is the decrease of administrative obstacles to business (Pokrajac, 2010, 257; Radukić \& Stanković, 2015).

The follow-up of comparative conditions and degree of ease of doing business for which the state is significantly responsible is done with the help of many indicators. The data of Global Entrepreneurship Monitor (GEM) and Doing-Business Index, World Bank Group (GEM 2017/2018 Global Report, n.d.; Doing Business-Measuring Business RegulationsWorld Bank Group, n.d.) are especially pronounced for their significance.

For fifteen years now World Bank has conducted the research in business ambience in all countries worldwide where the simplicity and ease of doing business is examined in a comparable way. Precisely, ease of doing business identifies how easy it is for a local entrepreneur to start small or medium enterprise according to current legal regulations in a country. Each year, this research spreads over new countries and territories.

Methodology of Doing Business does not include all business domains. The domains that are significant for business such as proximity of large markets, quality of infrastructure services (except those related to foreign exchange and getting electricity), safety of property against robbery and theft, transparency of public procurement, macroeconomic conditions or strength of fundamental institutions are not the subject of direct research by Ease of Doing Business. The indicators refer to local enterprises with limited responsibility that are doing business in largest business cities. Bearing in mind the fact that standard assumptions in data obtaining were used, the comparisons and parameters are valid in all economies. Even more, the data do not only reveal difficulties in doing business, but are also in the function of recognition of the origins of difficulties, thus supporting the creators of policies in design of necessary reforms.

The subject of the paper is the analysis of indicators of Ease of Doing Business in five Western Balkan countries based on the data of Doing Business Index in the period 20062018. Bearing in mind official commitment of all these countries to become EU members in reasonable period, the question whether the membership is per definitium provided by high ranking of Easy Doing Business is reasonably imposed (Despotović, Cvetanović \& Nedić, 2014).This is also the issue of research in this paper. In order to achieve an acceptable answer, besides the Western Balkan countries the paper includes Croatia in all analysed parameters of Easy Doing Business Index. We consider this approach acceptable due to the fact that Croatia became EU member in 2013, and is also a country that once was a part of former country together with four Western Balkan Countries that share the same state border now (Bosnia and Herzegovina, Serbia and Montenegro). The answer will be reached by analysing: 
a) Country ranking of Easy Doing Business; b) Ranking change and c) Distance to frontier measure (Doing Business, 2017).

Besides introduction, conclusion and literature, the paper includes three sections. The first section is related to the analysis of rankings of Ease of Doing Business in the countries of Western Balkans and Croatia as a control country based on Doing Business data in the period 2006-2018. The second section considers the changes of rankings of the analysed countries in the period 2006-2018, while the third considers the indicators of Distance to frontier measure for those countries.

\section{Rankings of Western Balkan Countries by Ease of Doing Business Index}

Ease of Doing Business provides total ranking of business conditions by indicators that define measures and standard regulations during life cycle of domestic small and medium enterprises. The countries are ranked from 1 to 190 by Ease of Doing Index, whereby 1 is the highest-ranking (best business conditions) and 190 is the lowest ranking. The Index is calculated as the average for each economy in the Table 1 in the following domains:

Table 1: 11 domains of business environment

\begin{tabular}{|c|c|}
\hline Indicator & What is measured by the indicator \\
\hline 1. Starting Business & $\begin{array}{l}\text { Procedure, time, expenses and minimum initial capital for } \\
\text { foundation of society with limited responsibility }\end{array}$ \\
\hline 2. Dealing with Construction Permits & $\begin{array}{l}\text { Procedure, time, and expenses for completion of all } \\
\text { formalities for obtaining construction permit }\end{array}$ \\
\hline 3. Getting electricity & $\begin{array}{l}\text { Procedure, time, and expenses for connection of the } \\
\text { building to electricity network, reliability of power supply } \\
\text { and electricity expenses }\end{array}$ \\
\hline 4. Registering Property & $\begin{array}{l}\text { Procedure, time, and expenses for transfer of property and } \\
\text { quality of cadastre administration }\end{array}$ \\
\hline 5. Getting Credit & System of credit information on crediting and Mortgage Law \\
\hline 6. Protecting Minority Investors & $\begin{array}{l}\text { The rights of minority owners in transactions with connected } \\
\text { legal entities and rights in corporate management }\end{array}$ \\
\hline 7. Paying Taxes & $\begin{array}{l}\text { Payments, time and total tax rate for the enterprise in order } \\
\text { to fulfil all tax duties }\end{array}$ \\
\hline 8. Trading Across Borders & $\begin{array}{l}\text { Time and expenses of export of the product with comparative } \\
\text { advantage }\end{array}$ \\
\hline 9. Enforcing Contracts & $\begin{array}{l}\text { Time and expenses for solving commercial dispute and } \\
\text { quality of court proceedings }\end{array}$ \\
\hline 10. Resolving Insolvency & $\begin{array}{l}\text { Time, expenses, outcome and rate of return of assets in resolving } \\
\text { insolvency and quality of legal bankruptcy framework }\end{array}$ \\
\hline 11. Labour Market Regulation & $\begin{array}{l}\text { Flexibility of employment regulations and quality of work } \\
\text { positions }\end{array}$ \\
\hline
\end{tabular}

Source: http://www.doingbusiness.org/

The ranking of Ease of Doing Business does not measure all aspects of business environment that are significant for enterprises and investors or that influence the competitiveness of economy. However, high ranking means that the government has created favourable regulatory environment for the work of economy subjects. 
The rankings of countries can be greatly beneficial to creators of economic policies (Cavusgil, Ghauri \& Akcal, 2012). In addition, it is useful to know the indicators that are comparable to other economies in relation to regional average. Table 2 shows the data on global ranking by Doing Business Index of Western Balkan Countries in the period 2006-2018.

Table 2. Doing Business - global rank (2006-2018.)

\begin{tabular}{|c|c|c|c|c|c|c|}
\hline $\begin{array}{l}\text { Country } \\
\text { Year/from total }\end{array}$ & Albania & BIH & Serbia & Montenegro & Macedonia & Croatia \\
\hline $2006 / 155$ & 117 & 87 & 92 & 92 & 81 & 118 \\
\hline $2007 / 175$ & 120 & 95 & 68 & 70 & 92 & 124 \\
\hline $2008 / 178$ & 136 & 105 & 86 & 81 & 75 & 97 \\
\hline $2009 / 181$ & 86 & 119 & 94 & 90 & 71 & 106 \\
\hline $2010 / 183$ & 82 & 116 & 88 & 71 & 32 & 103 \\
\hline 2011/183 & 82 & 110 & 89 & 66 & 38 & 84 \\
\hline $2012 / 183$ & 82 & 125 & 92 & 56 & 22 & 80 \\
\hline 2013/185 & 85 & 126 & 86 & 51 & 23 & 84 \\
\hline $2014 / 189$ & 90 & 131 & 93 & 44 & 25 & 89 \\
\hline $2015 / 189$ & 68 & 107 & 91 & 36 & 30 & 65 \\
\hline $2016 / 189$ & 97 & 79 & 59 & 46 & 12 & 40 \\
\hline $2017 / 190$ & 58 & 81 & 48 & 51 & 10 & 43 \\
\hline $2018 / 190$ & 65 & 86 & 43 & 42 & 11 & 51 \\
\hline
\end{tabular}

2006 - the State Union of Serbia and Montenegro

Source: http://www.doingbusiness.org/

The movement of rankings in the overall observed period (2006-2018) points to undoubted improvement of Western Balkan countries related to relative performances of Ease of Doing Business. All the analysed countries are significantly better positioned on the global list of Ease of Doing Business in 2018 in comparison to 2006. Macedonia made the most pronounced positive jump and improved from $81^{\text {st }}$ position in 2006 to $11^{\text {th }}$ position in 2018 (even $10^{\text {th }}$ position in 2017). The improvement of position was recorded for Serbia (from $92^{\text {nd }}$ to $43^{\text {rd }}$ position), Montenegro (from $92^{\text {nd }}$ to $42^{\text {nd }}$ position), Bosnia and Herzegovina (from $87^{\text {th }}$ to $86^{\text {th }}$ position) and Albania (from $117^{\text {th }}$ to $65^{\text {th }}$ position).

Figure 3. Doing Business - Global rank lines

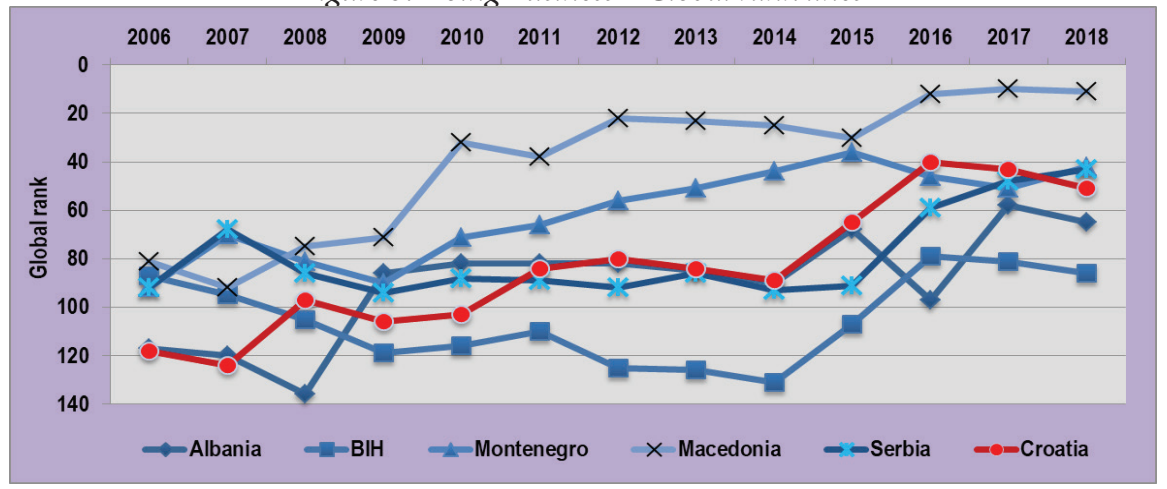

Source: $h t t p: / / w w w . d o i n g b u s i n e s s . o r g /$ 
Not only that total rank of Ease of Doing Business speaks a lot, but also the changes in ranking are very significant. Annual variations in ranking can show certain changes related to regulations, but they are mostly relative. Economic ranking can vary even due to improvement or decline of other economies. Some economies that conducted regulation reforms might stagnate (even fall) in case other outpace them, since their business regulation reforms produced more significant effect as measured by Ease of Doing Business.

\section{Distance to frontier measure}

Annual variations in total ranking do not completely reflect the change of business e environment or how the change in certain areas occurred. The estimation of distance of certain economies by best indicators and practice in the period after 2005 for specific domain of Ease of Doing Business, except getting electricity, can be followed by Distance to Frontier Measure (DTF). DTF illustrates the distance of economy from the "frontier" of value (complete fulfilment of demands) as well as changes in time. It shows to which degree the economy managed to close the gap until complete fulfilment of demands. Frontier value is defined as a result that originates from the most efficient world practice or best results achieved in specific parameters of indicators within DB in relation to all observed economies.

Table 3 shows data in changes of DTF for Western Balkan countries and Croatia in the period 2006-2018

Table 3. Doing Business - Distance to Frontier (DTF)

\begin{tabular}{|c|c|c|c|c|c|c|c|}
\hline $\begin{array}{l}\text { Country } \\
\text { Year/from total }\end{array}$ & Albania & BIH & Serbia & Montenegro & Macedonia & W. Balkan & Croatia \\
\hline $2006 / 155$ & 50.2 & 49.9 & 51.1 & & 54.3 & 51.8 & \\
\hline $2007 / 175$ & 50.8 & 50.5 & 54.3 & 58.8 & 56.5 & 55.0 & \\
\hline $2008 / 178$ & 51.4 & 50.9 & 55.2 & 59.1 & 58.1 & 55.8 & \\
\hline $2009 / 181$ & 61.7 & 52.7 & 55.9 & 61.9 & 61.0 & 57.9 & \\
\hline $2010 / 183$ & 62.17 & 52.04 & 58.33 & 60.69 & 63.3 & 58.6 & 61.4 \\
\hline 2011/183 & 62.34 & 53.24 & 59.05 & 61.66 & 63.66 & 59.4 & 61.82 \\
\hline $2012 / 183$ & 58.67 & 54.66 & 59.73 & 63.14 & 66.87 & 61.1 & 63.0 \\
\hline $2013 / 185$ & 58.9 & 55.17 & 60.63 & 65.34 & 70.15 & 62.8 & 62.7 \\
\hline $2014 / 189$ & 59.37 & 56.09 & 60.64 & 67.38 & 74.21 & 64.6 & 65.6 \\
\hline $2015 / 189$ & 66.77 & 63.36 & 65.25 & 71.05 & 79.69 & 69.8 & 71.7 \\
\hline $2016 / 189$ & 60.5 & 63.71 & 68.41 & 71.85 & 80.18 & 71.0 & 71.4 \\
\hline $2017 / 190$ & 67.74 & 63.87 & 72.87 & 71.54 & 81.39 & 72.4 & 71.65 \\
\hline $2018 / 190$ & 68.7 & 64.2 & 73.13 & 73.18 & 81.18 & 72.9 & 71.7 \\
\hline
\end{tabular}

Source: http://www.doingbusiness.org/

It can be noticed that Montenegro had better while Serbia had worse result than the WB average in the longer part of the observed period. In the first year after its independence, Montenegro achieved significant advantage, which it held for longer period and which is better that WB average. It was in 2016 that these two economies (Serbia and Montenegro) 
became equal again (in 2018 Montenegro took $42^{\text {nd }}$ and Serbia $43^{\text {rd }}$ positions). In 2018, besides Macedonia as a leader in the group, Serbia and Montenegro achieved better results in comparison to Croatia, despite its membership in EU.

\section{Conclusion}

In the period 2006-2017, Western Balkan countries significantly, but still insufficiently improved in creation of better conditions for business activities. By comparing three Doing Business indicators a) country ranking, b) change of rank and c) change of Distance to frontier measure it can be concluded that the EU membership need not necessarily mean the presence of more favourable conditions in comparison to those that exist in non-member countries of this regional economic integration. All the observed Western Balkan countries have more favourable dynamics of Doing Business Index in comparison to Croatia which is an EU member. Macedonia achieved considerably strong growth as an indisputable leader of the region in this domain. Globally speaking, Macedonia entered the most successful fifth of the world countries in 2017 by the indicators of Ease of Doing Business; this could be a precious indicator to other Western Balkan countries, which also made an indisputable progress in the analysed period. However, we have to mention that the weaker dynamics of Croatia in this domain was also a result of its duty to harmonize the reforms of business ambience with other EU members. Therefore, although it looks absurd, the bearers of economic policy of Western Balkan countries have the potential of larger manoeuvring space for doing reforms in business ambience at pre-membership stage; Macedonia is an example that encourages more dynamic approach to the process of achieving conditions of Ease of Doing Business in global leaders.

\section{References}

Cavusgil, S. T., Ghauri, P. N., \& Akcal, A. A. (2012). Doing business in emerging markets. Sage.

Data from the Doing Business Project. (n.d.). Retrieved July 9, 2018, from http://www. doingbusiness.org/data. World Bank Group

Despotović, D., Cvetanović, S., \& Nedić, V. (2014). Innovativeness and competitiveness of the Western Balkan countries and selected EU member states. Industrija, 42(1), 27-45.

Doing Business - Measuring Business Regulations - World Bank Group. (n.d.). Retrieved July 9, 2018, from http://www.doingbusiness.org/. World Bank

Doing Business (2017). Distance to Frontier and Ease of Doing Business Ranking. A World Bank Group Flagship Report.

Economy Profle of Croatia 2018. (n.d.). Retrieved July 9, 2018, from http://www. doingbusiness.org/data. Data from the Doing Business Project. World Bank Group

GEM 2017 / 2018 Global Report. (n.d.). Retrieved July 9, 2018, from https://www. gemconsortium.org/. Global Entrepreneurship Monitor

Lakoća poslovanja 2018. Bosna i Hercegovina (2017), Sarajevo: Federalni zavod za programiranje razvoja. 
Pokrajac, S. (2010). Preduzetništvo: izazovi i putevi „kreativne destrukcije” privrede Srbije, Mašinski fakultet, Beograd.

Prokopović, B. B., Jelić, M. A., \& Veličković, G. (2017). Implication of better economic conditions. Ekonomika, 63(3), 25-34.

Radukić, S., \& Stanković, J. (2015). Evaluation of local business environment in the Republic of Serbia. Procedia Economics and Finance, 19, 353-363. 